\title{
PENGARUH TEMAN SEBAYA TERHADAP PERILAKU JAJAN SEHAT ANAK DI SDN KARANGSARI 2, TANGERANG
}

\author{
Lindawati \\ Poltekes Kemenkes Banten \\ Korespondensi: lindawati.nasrun@yahoo.co.id
}

\begin{abstract}
ABSTARK
Elementary student's behavior on buy street food is potentially dangerous with the worst case is death. That potential comes from the chances of children buy some food which aren't clean and safe enough to their health. One of its factor which is affect their habit is their friend in the same age whose they imitate their decision on or learn their requirement to choose street food. The purpose of this research was to know the effect of friend in the same age on SDN Karangsari 2 student's behavior on buy street food. The design of this research was quasi experiment and it was carried out in Mei-November 2017 at SDN Karangsari 2, Tangerang. The population was a whole student of grade 5 with its samples were a whole population, 55 students. The few dominant samples out of those 55 students were 10 students, they were chose from how they influence others on their decide to buy street food. The research was analyzed by $t$ dependent test and showed the result that there was not an effect of friend in the same age on SDN Karangsari 2, Tangerang on their behavior on buy street food $(p=0,468)$. Its proposed that school form a health section who concern about street food in hope student could choose healthy and clean street foods.
\end{abstract}

Keywords: Behavior, Friend in the same age, Street food,

\begin{abstract}
ABSTRAK
Prilaku jajan sangat membahayakan kesehatan anak bila salah dalam memilih dan membeli makanan Bahkan bisa menyebabkan kematian. Salah satu faktor yang mempengaruhi prilaku jajan anak SD adalah teman sebaya, dimana anak meniru atau mempelajari kebiasaan teman sebaya akan mempengaruhi pengambilan keputusan dalam memilih jajanan. Tujuan penelitian ini adalah Mengetahui pengaruh teman sebaya terhadap perilaku jajan anak SDN Karangsari 2 Tangerang. Desain Penelitian : quasi ekspriment dengan Lokasi Penelitian di SDN Karangsari 2 dan waktu penelitian bulan Mei -November 2017. Popoulasi seluruh siswa kelas 5 dengan sampel penelitian adalah total populasi yang berjumlah 55 orang. Respoden yang berperan sebagai anak yang dominan dan bertugas mempengaruhi anak lain berjumlah 10 orang dan sisanya sebagai respoden yang akan diteliti. Analisa mengunakan uji $t$ dependent. Hasil penelitan menunjukan tidak ada pengaruh teman sebaya terhadap prilaku jajan sehat pada anak SDN Karangsari $2(\mathrm{p}=0,468)$ dan dianjurkan pada sekolah untuk membentuk kader kesehatan tentang jajanan sehat yang bisa membantu sekolah untuk menumbuhkan prilaku jajan sehat pada anak SDN karangsari 2 Kota Tangerang
\end{abstract}

Kata Kunci: Perilaku Jajan, Teman sebaya 


\section{PENDAHULUAN}

Hampir semua anak memiliki kebiasaan jajan terutama ketika berada di sekolah atau di luar rumah (Muhilal dkk, 2006 dalam Alfid (2012)). Kebiasaan tersebut menjadi suatu prilaku yang sering ditemui dan sulit dicegah oleh orangtua. Prilaku jajan bisa berdampak positif bila anak dapat memilih makanan sehat dan bergizi, namun akan berdampak negatif bila anak salah dalam memilih jajan tampa memperhatikan kandungan makanan yang berbahaya bagi kesehatan karena ada zat pengawet, pemanis tambahan dan zat pewarna tekstil. Kadangkala anak tidak memperhatikan kadaluarsa dan kebersihan makananan (Sihadi, 2004). Prilaku ini sangat membahayakan kesehatan anak.

Penyakit yang diderita oleh anak SD terkait perilaku jajanan tidak sehat diantaranya cacingan 40-60\%, anemia $23,2 \%$, karies dan periodontal $74,4 \%$. penyakit menular pada anak usia sekolah karena sekolah merupakan lokasi sumber penularan penyakit infeksi pada anak (Depkes, 2005).

Data surveilan KLB keracunan pangan tahun 2010 terdapat 163 kejadian. Berdasarkan jenis pangannya, jajanan berkontribusi terhadap kasus keracunan sebesar 13,5\%. Menurut data Badan Pengawas Obat dan Makanan (BPOM) pada 2010, sekolah menempati urutan kedua
(26,9\%) setelah tempat tinggal $(56,52 \%)$ kasus keracunan pangan di Indonesia. Data BPOM tahun 2010 menunjukkan adanya jajanan yang tidak memenuhi syarat dengan ditemukannya dari 2.984 sampel yang diuji, $45 \%$ tidak memenuhi syarat karena mengandung boraks, formalin, rhodamin B. Bahan-bahan ini dapat terakumulasi pada tubuh manusia dan bersifat karsinogenik yang dalam jangka panjang menyebabkan penyakit-penyakit seperti kanker dan tumor pada organ tubuh manusia (Anita, 2006) dan ada juga yang berakhir dengan kematian. Hasil penelitian tersebut menunjukkan rendahnya perlindungan pada anak sekolah (Permata, 2010).

Beberapa faktor yang berpengaruh terhadap prilaku jajan anak dalam memilh makanan adalah keluarga dan sekolah (Simon et al.,1984) serta teman sebaya. Anak ingin diterima serta diakui keberadaannya oleh teman sebaya sehingga prilaku jajan seorang teman akan diikuti oleh anak lain.

Anak sekolah dasar sering membeli jajanan di sekolah. Anak cenderung untuk membeli jajanan yang tersedia paling dekat dengan keberadaannya (Peilin, 2004 dalam Lila Oktania Saputri, 2012). Meniru atau mempelajari kebiasaan teman sebaya akan mempengaruhi pengambilan keputusan dalam memilih jajanan (Bellisle F., 2004 
dalam Bondika Ariandani Aprillia, Fillah Fithra Dieny, 2011). Menurut Safriana 2012 dalam Nurul Iklima 2017 bahwa anak-anak usia sekolah sudah cenderung dapat memilih makanan yang disukai dan mana yang tidak. Anak-anak mempunyai sifat yang berubah-ubah terhadap makanan dan selalu ingin mencoba makanan yang baru dikenalnya. Seringkali anak memilih makanan yang salah terlebih lagi jika tidak dibimbing oleh orang tuanya. Selain itu anak lebih sering menghabiskan waktu diluar rumah sehingga anak lebih sering menemukan aneka jajanan baik yang dijual disekitar sekolah, lingkungan bermain ataupun pemberian teman.

Dari hasil studi pendahuluan ke SDN Karangsari 2 kepada 20 orang anak SD kelas V , 17 orang siswa jajan setiap hari di sekolah dengan pilihan minuman es teh, mie, somay serta makanan lain. Mereka jajan karena tidak bawa bekal ke sekolah dan diantara mereka pernah mengalami sakit perut setelah jajan. Hasil wawancara juga dikethaui bahwa mereka jajan sering bersama - sama dengan teman dan memilih makanan yang sama. Kadangkala mereka bawa bekal bersama - sama yang diawali dengan janji dan makan secara bersamasama pula.

Penelitian ini memiliki tujuan yaitu mengetahui pengaruh teman sebaya terhadap perilaku jajanan sehat anak SDN Karangsari 2 Tangerang.

\section{METODE}

Desain penelitian ini adalah quasi eksprimen (one group design) yaitu kelompok subjek diobservasi sebelum intervensi dan setelah intervensi. Populasi dalam penelitian ini adalah siswa kelas 5 SDN Karangsari 2 Kota Tangerang. Sampel penelitian adalah total populasi yaitu seluruh siswa kelas 5 SDN Karangsari Karangsari 2 Kota Tangerang yang memenuhi kriteria inklusi yaitu siswa/siswi yang sehat dan bersedia menjadi responden.

Variabel penelitian diukur dengan instrumen berupa kuisioner dengan skala ordinal yang menggunakan wawancara sebagai cara ukur. Penelitian ini diadakan di SDN Karangsari 2 Kota Tangerang pada bulan Mei -November 2017.

Pelaksanaan pengumpulan data dilakukan dengan penetapan sampel dan diwawancara agar dapat mengetahui teman sebayanya yang paling akrab serta perilaku jajannya selama di sekolah. Kemudian responden yang dominan akan digali pengetahuannya tentang jajan sehat setelah itu diberikan perlakuan dengan memberikan informasi tentang pentingnya memilih jajanan sehat serta diinstruksikan untuk mengajak temannya memilih makanan sehat 
juga. Respoden yang dominan dan dianggap mampu untuk mengajak teman-temannya berprilaku jajan sehat dari siswa SDN Karangsari 2 berjumlah 10 orang dan masing - masing anak memiliki 4-5 orang anak yang menjadi tanggung jawabnya untuk diberikan informasi tentang makanan sehat dan dajak untuk memilih jajanan sehat.

Analisis data menggunakan analisa univariat dan bivariat. Analisa bivariat mempergunakan uji statistik T-Tes dependent, kemudian diuji dengan $\alpha=5 \%$ $(0,05)$.Bila $p$-value $\leq 0.05$ maka perbedaan yang terjadi bermakna (signifikan).

\section{HASIL DAN PEMBAHASAN}

\section{a. Distribusi frekuensi jenis jajanan}

\section{yang dikomsumsi distribusi}

Tabel 1. Daftar kelompok jajanan terbanyak yang sering di komsumsi oleh respoden

\begin{tabular}{ll}
\hline NO & \multicolumn{2}{c}{ JENIS JAJANAN } \\
1 & $\begin{array}{l}\text { Makanan yang diporsikan } \\
\text { (Mie,batagor,bakso,dan siomay) }\end{array}$ \\
2 & $\begin{array}{l}\text { Makanan panganan (gorengan, } \\
\text { kue }- \text { kue) }\end{array}$ \\
3 & Minuman (es,minuman kemasan) \\
4 & Chiki, kerupuk, / keripik, biskuit \\
\hline
\end{tabular}

Pemilihan jenis jajanan ini hampir sama dengan hasil penelitian - penelitan lain yang berhubungan dengan jajanan pada anak usia sekolah seperti hasil penlitian Safriana (2012) dan Eunike Sri Tyas Suci (2008). Tingginya peminat makanan ini karena makanan ini yang paling banyak dijual, mudah ditemui, dan rasanya yang gurih, enak serta mengenyangkan dalam waktu yang lama.

\section{b. Frekuensi prilaku jajan anak yang jajan setiap hari}

Tabel 2. Distribusi Prilaku Jajan Responden Sebelum Intervensi

\begin{tabular}{lcc}
\hline $\begin{array}{l}\text { Prilaku } \\
\text { jajan }\end{array}$ & Frekuensi & $\begin{array}{l}\text { Persentase } \\
(\%)\end{array}$ \\
\hline $\begin{array}{l}\text { Tidak } \\
\text { pernah }\end{array}$ & 2 & 5,3 \\
$\begin{array}{l}\text { Kadang- } \\
\text { kadang }\end{array}$ & 16 & 42,1 \\
$\begin{array}{l}\text { Setiap } \\
\text { hari }\end{array}$ & 20 & 52,6 \\
\hline Jumlah & 38 & 100,0 \\
\hline
\end{tabular}

Tabel 3. Distribusi Prilaku Jajan Responden Setelah Intervensi

\begin{tabular}{lcc}
\hline $\begin{array}{l}\text { Prilaku } \\
\text { jajan }\end{array}$ & Frekuensi & $\begin{array}{l}\text { Persentase } \\
(\%)\end{array}$ \\
\hline $\begin{array}{l}\text { Tidak } \\
\text { pernah }\end{array}$ & 0 & 0 \\
$\begin{array}{l}\text { Kadang- } \\
\text { kadang }\end{array}$ & 20 & 52,6 \\
$\begin{array}{l}\text { Setiap } \\
\text { hari }\end{array}$ & 18 & 47,4 \\
\hline Jumlah & 38 & 100,0 \\
\hline
\end{tabular}

Berdasarkan tabel di atas dapat terlihat ada perubahan prilaku jajan yang tidak pernah semula 2 orang menjadi tidak ada sama sekali anak yang jajan. Perubahan ini memang kecil bila dilihat secara individual dan secara statistik tidak menujukan hasil yang signifikan $(\mathrm{p}=0,468)$. 
c. Distribusi frekuensi prilaku jajan anak yang mengikuti pilihan teman sebaya

Tabel 4. Distribusi Prilaku Prilaku Jajan Responden karena Melihat Temannya Jajan Sebelum Intervensi

\begin{tabular}{lcc}
\hline $\begin{array}{l}\text { Prilaku } \\
\text { jajan }\end{array}$ & Frekuensi & $\begin{array}{l}\text { Persentase } \\
(\%)\end{array}$ \\
\hline $\begin{array}{l}\text { Tidak } \\
\text { pernah }\end{array}$ & 12 & 31,6 \\
$\begin{array}{l}\text { Kadang- } \\
\text { kadang }\end{array}$ & 12 & 31,6 \\
$\begin{array}{l}\text { Setiap } \\
\text { hari }\end{array}$ & 14 & 36,8 \\
\hline Jumlah & 38 & 100,0 \\
\hline
\end{tabular}

Tabel 5. Distribusi Prilaku Jajan Responden karena Melihat Temannya Jajan Sesudah Intervensi

\begin{tabular}{lcc}
\hline $\begin{array}{l}\text { Prilaku } \\
\text { sarapan }\end{array}$ & Frekuensi & $\begin{array}{l}\text { Persentase } \\
(\%)\end{array}$ \\
\hline $\begin{array}{l}\text { Tidak } \\
\text { pernah }\end{array}$ & 13 & 34,2 \\
$\begin{array}{l}\text { Kadang- } \\
\text { kadang }\end{array}$ & 15 & 39,5 \\
$\begin{array}{l}\text { Setiap } \\
\text { hari }\end{array}$ & 10 & 26,3 \\
\hline Jumlah & 38 & 100,0 \\
\hline
\end{tabular}

Pola hasil penelitian ini juga terdapat pada prilaku jajan respoden yang timbul karena melihat temannya jajan bisa dilihat pada tabel dimana sebelum intervensi respoden yang terbanyak adalah setiap hari 14 orang $(36,8 \%)$ dan setelah intervensi sebanyak 10 orang.

\section{d. Distribusi frekuensi prilaku jajan responden yang mengikuti pilihan teman}

Tabel 6. Distribusi Prilaku Jajan Responden yang Mengikuti Pilihan Teman Sebelum Intervensi

\begin{tabular}{lcc}
\hline $\begin{array}{l}\text { Prilaku } \\
\text { jajan }\end{array}$ & Frekuensi & $\begin{array}{l}\text { Persentase } \\
(\%)\end{array}$ \\
\hline $\begin{array}{l}\text { Tidak } \\
\text { pernah }\end{array}$ & 20 & 52,6 \\
$\begin{array}{l}\text { Kadang- } \\
\text { kadang }\end{array}$ & 9 & 23,7 \\
$\begin{array}{l}\text { Setiap } \\
\text { hari }\end{array}$ & 9 & 23,7 \\
\hline Jumlah & 38 & 100,0 \\
\hline
\end{tabular}

Tabel 7. Distribusi prilaku jajan responden yang mengikuti pilihan teman sesudah intervensi

\begin{tabular}{lcc}
\hline $\begin{array}{l}\text { Prilaku } \\
\text { sarapan }\end{array}$ & Frekuensi & $\begin{array}{l}\text { Persentase } \\
(\%)\end{array}$ \\
\hline $\begin{array}{l}\text { Tidak } \\
\text { pernah }\end{array}$ & 18 & 47,4 \\
$\begin{array}{l}\text { Kadang- } \\
\text { kadang }\end{array}$ & 13 & 34,2 \\
$\begin{array}{l}\text { Setiap } \\
\text { hari }\end{array}$ & 7 & 23,7 \\
\hline Jumlah & 38 & 100,0 \\
\hline
\end{tabular}

Begitu juga prilaku jajan anak yang mengikuti pilihan teman sebelum tindakan sebagian besar adalah tidak pernah yaitu $52 \%$ dan setelah tindakan $47 \%$. Menurut Sulistyoningsih, 2011, dalam Ledi Miha, $\mathrm{dkk}, 2012$, pengaruh teman sebaya terhadap perilaku jajan anak sangat besar karena anak usia sekolah lebih banyak menghabiskan waktu dengan teman sebayanya dibandingkan dengan keluarganya. Peningkatan pengaruh teman sebaya berdampak terhadap perilaku perihal pola dan jenis jajanan pilihan mereka. Anak secara tiba-tiba meminta suatu jenis 
makanan jajanan baru atau menolak makanan jajanan pilihan mereka terdahulu, akibat rekomendasi dari teman-teman sebayanya, namun teori diatas tidak sama dengan hasil penelitian ini yang akan dibahas di bagian selanjutnya.

\section{e. Pengaruh teman sebaya terhadap perilaku jajan anak SDN Karangsari 2 Tangerang.}

Tabel 8. Hasil Uji Statistik Perbedaan Pengaruh Teman Sebaya Terhadap Prilaku Jajan Responden

\begin{tabular}{lcccc}
\hline \multicolumn{1}{c}{ Prilaku } & Rerata & Selisih & IK & Nilai \\
& & & $95 \%$ & $\mathrm{p}$ \\
Prilaku & 11,29 & 0,42 & & \\
$\begin{array}{l}\text { sebelum } \\
\text { intervensi }\end{array}$ & $(2,44)$ & $(3,53)$ & $0,74-$ & 0,468 \\
\end{tabular}

Prilaku $\quad 11,71$

setelah $\quad(2,77)$

intervensi

Tabel di atas menjelaskan bahwa rerata scor prilaku sebelum tindakan sebesar 11,29 dan rerata setelah tindakan 11,71 yang memiliki selisih 0,42 . Hal ini menunjukan ada perbedaan prilaku sebelum dengan setelah dilakukan tindakan di mana terjadi peningkatan prilaku jajan sehat sebesar 0,42 , namun hasil uji statistic $t$ dependent test nilai $\mathrm{p}$ menunjukan 0,468 yang berarti bahwa tidak ada pengaruh teman sebaya terhadap prilaku jajan sehat responden.
Hasil penelitian ini sama dengan beberapa penelitian lainnya seperti penelitan Ledy Miha Radja, Marni, dkk (2012) tentang Pengaruh Kebiasaan Sarapan Dan Teman Sebaya Terhadap Perilaku Jajan Siswa Di Kota Kupang. Penelitian Safriana, (2012) juga menunjukan tidak adanya pengaruh teman sebaya terhadap pemilhan jajan pada siswa SDN Garot Kecamatan Darul Imarah Kabupaten Aceh Besar Tahun 2012, sedangkan hasil penelitian Nikita dewayani, Sukihananto (2013) memperlihatkan tidak adanya hubungan pengetahuan ibu dengan prilaku jajanan sekolah.

Tidak adanya pengaruh teman sebaya terhadap perilaku jajan sehat anak pada penelitian ini bisa disebabkan karena ada beberapa faktor antara lain faktor psikologi anak yang menyenangi makanan, (Suharjo,2013 ) dan dukungan orangtua lebih besar pengaruhnya dari teman sebaya. Walaupun mereka jajan bersama, anak tetap memilih makanan yang disenangi dan sudah sering dimakan serta disediakan oleh orangtua mereka

\section{SIMPULAN}

1. Prilaku jajan siswa SDN Karangsari 2 Tangerang sebelum intervensi yaitu sebagian besar jajan setiap hari $52.6 \%$ dan setelah intervensi menjadi $47 \%$ 
2. Jenis jajanan yang sering dikomsumsi anak yang terbanyak adalah makanan yang diporsikan seperti mie, bakso, siomay dan makanan panganan seperti gorengan dan kue kecil

3. Prilaku jajan siswa SDN Karangsari 2 Tangerang karena melihat temannya jajan sebelum intervensi yaitu jajan setiap hari sebagian besar $14 \%$ dan setelah intervensi yang jajan setiap hari karena melihat temannya $26.3 \%$

4. Prilaku pemilihan jajan siswa SDN Karangsari 2 Tangerang karena melihat pilihan temannya jajan sebelum intervensi sebagian besar tidak pernah sebanyak 20 orang $(52,6 \%)$ dan setelah intervensi yang jajan setiap hari karena melihat temannya $47,4 \%$

5. Bahwa tidak ada pengaruh teman sebaya terhadap prilaku jajan sehat anak SDN Karangsari 2

\section{DAFTAR PUSTAKA}

Anita. (2006). Analisis keamanan pangan jajanan dan upaya peningkatan mutunya. Skripsi. Fakultas Teknologi Pertanian Institut Pertanian Bogor

Ariandani A.,Bondika, Fillah F. 2011. Faktor yang Berhubungan dengan Pemilihan Makanan Jajanan pada Anak Sekolah Dasar

Depkes RI. 2005. Aspek Gizi Makanan Jajanan. Jakarta: Direktorat Jenderal Pembinaan Kesehatan Masyarakat.
Depkes RI. 2004. Hygiene Sanitasi Makanan dan Minuman (HSMM). Jakarta: Buku Pedoman Akademi Penilik Kesehatan.

Dewayan, Nikita, Sukihananto. 2013. Prilaku Anak Sekolah Dalam Pemilihan Jajanan Sekolah tidak Dipengaruhi oleh pengetahuan Ibu tentang Pedoman Umum Gizi Seimbang

Harper, Laura J. 1989. Pangan, Gizi dan Pertanian. Jakarta: Universitas Indonesia.

Hartup, W. W. 1992. Peer relations in early and middle childhood. In V. B. Van Hasselt \& M. Hersen (Eds.), Handbook of social development: A lifespan perspective. New York: Plenum press

Irianto, K. 2007. Gizi dan Pola Hidup Sehat. Bandung: CV Yrama Widya.

Iklima, N. 2017. Gambaran Pemilihan Makanan Jajanan pada Anak SD, Jurnal Keperawatan BSI, 5 (1)

Lila Oktania Saputri, Kristiawati, dkk,. 2012. Peningkatan pengetahuan dan sikap dalam pemilihan jajanan sehat menggunakan alat permainan edukatif ular tangga

Notoatmodjo. 2003. Pendidikan dan Perilaku kesehatan. Jakarta: Rineka Cipta.

Safriana. 2012. Prilaku memilih jajanan pada Siswa SDN Garot Kec Darul Imamah, Kab Aceh Besar

Suci, E., Sri T., .2009. Gambaran Prilaku Jajan Murid SD di Jakarta, Psikobuana $1(1)$

Sihadi. 2004. Makanan jajanan bagi anak sekolah. Jurnal kedokteran Yarsi, 2 
Simon, Morton BC, Coates TJ, Saylor KE, Seroghy E, Barofsky I. 1984. Great sensation: A program to encourage heart healthy snacking by high school students. J School Health 54:280-291.

Permata 2010, Jajanan anak sekolah berbahaya,

Tri A., Alfid. 2012. Pengaruh Peer Group Support Terhadap Perilaku Jajanan Sehat Siswa Kelas 5 SDN Ajung 2 Kalisat Jember

Wong, Donna L. 2008. Buku Ajar Keperawatan Pediatrik. Jakarta: EGC 